\title{
Konflik Sunni-Syiah dan dampaknya terhadap komunikasi intra- religius pada komunitas di Sampang-Madura
}

\author{
Sunni-Syia conflict and its effects to intra-religious community in \\ Sampang, Madura
}

\author{
Rachmah Ida $^{1}$ \& Laurentius Dyson ${ }^{2}$ \\ 1) Komunikasi FISIP UNAIR \& Centre for Muslim State \& Society, UWA, Australia \\ 2) Antropologi, FISIP, Universitas Airlangga, Surabaya, Indonesia \\ Korespondensi: Komunikasi FISIP UNAIR, Jalan Airlangga 4-6 Surabaya 60286, Indonesia \\ E-mail: rachmahda.unair@gmail.com
}

\begin{abstract}
The conflict between the Muslim Sunni and Shia, hereafter Sunni-Shia conflict, occurred in Sampang on August 2012 was recognised as a group identity conflict. The existence of Muslim Shia community as minority amongst the Sunni majority in Madura has long become the latent intra-faith clash in this Island. This study explores the socio-cultural and political aspects of Sunni-Shia conflict in Sampang District of Madura and examines the views of these two communities about their religius stance, values, and socio-cultural practices in their places, and how they have perceived other religius group identity regarded as distinct to each other. Methods applied for this study are qualitative survey using two approaches i.e. socio-cultural historic and inter-cultural communication. The data were gathered through depth interviews, observations, and secondary documentations sourced from media news and articles, government policy and relevant literatures. This study found that the root of the conflict was begun from the familial (brotherhood) clash, which then extended into the clash between Sunni and Shia communities and the issue of religius ideology and identity. The difference on their opinion, perception, and attitude of the Sunni and Shia groups have become the key issues of these two groups to fight their religius identities interest and their beief upon the true of Islam according to their version. As a result, their intra-religius life and communication between these two groups have become paralised and stucked.
\end{abstract}

Keywords: Sunni, Shia, intra-faith conflict, intra-religius communication, ethno-communal conflict

\begin{abstract}
Abstrak
Konflik antara Muslim Sunni dan Syiah, selanjutnya disebut konflik Sunni-Syiah, yang terjadi di Sampang pada Agustus 2012 ditandai sebagai konflik identitas kelompok. Keberadaan komunitas Muslim Syiah sebagai minoritas diantara mayoritas Sunni di Madura telah lama menjadi konflik intra-religius tersembunyi di pulau ini. Studi ini menggali aspek-aspek sosio-kultural dan politik dari konflik Sunni-Syiah di Kabupaten Sampang Madura dan menjelaskan pandangan-pandangan dua komunitas ini tentang keyakinan agamanya, nilai-nilai agama yang dianut dan praktik-praktik sosio-kultural di tempat mereka, dan bagaimana mereka mempersepsi kelompok identitas agama lain yang berbeda satu sama lain. Metode yang digunakan untuk studi ini adalah survey kualitatif dengan dua pendekatan yakni sosio-kultural historis dan Komunikasi Antar-Budaya. Studi ini menggunakan teknik wawancara mendalam, observasi, dan menggunakan data-data sekunder bersumber dari media massa, kebijakan pemerintah, dan literatur yang relevan. Studi ini menemukan bahwa akar masalah konflik yang terjadi bermula dari persoalan keluarga yang meluas pada persoalan komunitas/komunal, yang kemudian menjalar pada persoalan ideology dan identitas kelompok agama. Perbedaan pandangan, persepsi dan sikap kelompok Sunni dan Syiah menjadi isu kunci keduanya untuk memperjuangkan kepentingan identitas agama dan keyakinan atas Islam yang benar versi masing-masing. Akibatnya, dampak terhadap kehidupan Komunikasi intra-religius menjadi macet dan lumpuh diantara kedua kelompok tersebut.
\end{abstract}

Kata kunci: Sunni, Syiah, konflik intra-agama, komunikasi intra-religius, konflik etno-komunal 


\section{Pendahuluan}

"Indonesia is a violent country" (Coloombijn \& Thomaslindbald 2002). Konflik di Indonesia menjadi bagian dari "rutinitas dan keseharian" masyarakat Indonesia. Konflik yang selama 30 tahun rezim ORBA di 'tabu'kan oleh negara dan warga masyarakat, seolah kini menjadi tindakan-nyata yang sah, lazim dan dapat dibenarkan dalam sistem tata-kehidupan berasaskan demokrasi. Intensitas dan persebaran kejadian konflik menguat sejalan dengan multiplikasi kejadian konflik yang diberitakan melalui berita-berita tentang konflik sosial di media massa.

Menurut Varshney et al. (2004:23) dengan mengambil pelajaran konflik yang berlangsung di Indonesia selama 1990-2003 memetakan kecenderungan kejadian konflik yang meningkat ekskalasinya terutama setelah rezim Orde Baru runtuh. Varsney menunjukkan angka tertinggi terjadinya konflik agama dan etnik di Indonesia meningkat tajam di tahun 2000 dengan jumlah korban meninggal diperkirakan sekitar 722 jiwa manusia.

Diperkirakan, beberapa faktor yang bertanggung jawab atas kejadian konflik tersebut adalah: (1) political power stress yang diderita kekuatan-kekuatan yang selama ini "dibelenggu" oleh rezim otoritarian ORBA; (2) perubahan rezim politik ketatanegaraan yang memberikan kebebasan kuat kepada setiap orang dan kelompok sosial untuk mengekspresikan keinginannya secara lebih bebas; (3) social-economic distress yang diderita banyak orang akibat krisis ekonomi di tahun 1997 yang dampaknya masih terasakan hingga kini; (4) kesadaran akan kebutuhan akan penghargaan sosial atas eksistensi kelompok/identitas yang makin menguat di kalangan komunitas lokal di berbagai kawasan di Indonesia.

Berdasarkan jenisnya, konflik yang terjadi di Indonesia ini sebagian besar merupakan konflik yang berlatar belakang SARA (Suku, Agama, Ras \& Antar Golongan). Seperti konflik sosial berlatar belakang Agama di Ambon (1999-2002), di Poso (1998-2001) kemudian konflik bermotif suku atau etnis di Sampit (2001) yaitu antara suku Dayak dan Suku Madura sebagai pendatang serta akhir-akhir ini yaitu konflik di Lampung Selatan (2012) dan di Sampang Madura (2012) yang memiliki motif SARA di dalamnya.

Bagaimana konflik di Jawa Timur terkait dengan persoalan inter/intra-religius? Studi yang dilakukan oleh Yayasan Wakaf Paramadina (YWP), Magister Perdamaian dan Resolusi Konflik, Universitas Gadjah Mada (MPRK-UGM) dan The Asia Foundation (TAF) tahun 2009 menemukan sebanyak 832 insiden konflik keagamaan yang terjadi di Indonesia dalam rentang periode Januari 1990 hingga Agustus 2008. Pola persebaran konflik keagamaan di Indonesia lebih luas dibandingkan dengan aksi kekerasan.

Studi di atas menunjukkan pola persebaran konflik keagamaan tertinggi DKI Jakarta 308, disusul Jawa Barat 102, Sulawesi Tengah 76 dan urutan keempat Jawa Timur 65 insiden. Jenis aksi kekerasan digolongkan ke dalam penyerangan, bentrokan dan kerusuhan/amuk massa. Data ini memperlihatkan bahwa aksi massa merupakan bentuk yang dipandang paling efektif oleh masyarakat dalam merespons isu-isu konflik keagamaan, termasuk di Jawa Timur. Berkenaan dengan aksi massa, jenis aksi penyerangan merupakan insiden kekerasan yang tertinggi, disusul oleh bentrokan dan kerusuhan/amuk massa.

Konflik inter-religius Sunni-Syiah di Sampang, di tahun 2012 merupakan konflik atas eksistensi kelompok/identitas yang makin menguat di kalangan komunitas Sampang. Secara sosio-budaya, perbedaan identitas dan religius di kalangan kelompok-kelompok sosial yang hidup bersama di kawasan ini menjelaskan mengapa konflik harus berlangsung.

Perbedaan mazhab atau ideologi yang dianut oleh masing-masing pihak bersengketa menjadikan friksi sosial dapat berubah menjadi konflik yang nyata. Konflik yang berlangsung antara para penganut mazhab pada Sunni versus Syiah terjadi secara dramatis di ruang masyarakat sipil di Indonesia. Konflik yang berlangsung di ruang masyarakat Sampang menghasilkan dampak yang 
paling "beraneka warna" (karena beragamnya persoalan yang dijadikan obyek konflik) dan berlangsung dengan cukup memprihatinkan (berujung pada kematian, cedera, dan kerusakan).

Pemunculan berita tentang konflik di koran dan televisi telah membuat "proses sosialisasi" tanpa disadari telah membentuk opini tentang perbedaan kepada warga masyarakat di lain tempat untuk meniru dan mengimitasi "proses-proses penyelesaian masalah melalui jalan kekerasan" bagi persoalan serupa yang dijumpai di lokalitas masing-masing. Konflik inter-religius Sunni-Syiah di Sampang pada tanggal 26 Agustus 2012 tepatnya di desa Karang Gayam kecamatan Omben dan Desa Bluuran Kecamatan Karang Penang Kabupaten Sampang Jawa Timur merupakan puncak terjadinya konflik kelompok Islam Syiah dan Sunni yang disertai aksi kekerasan dan menyebabkan satu orang tewas. Bahkan Kapolsek Omben, AKP Aris, turut menjadi korban dalam bentrokan tetsebut. Satu warga yang tewas, dua orang mengalami kritis, 37 rumah terbakar akibat bentrokan tersebut. Aksi kekerasan dan bentrokan ini melibatkan kurang lebih 500 orang (Antara 2012).

Pembakaran rumah jamaah Syiah di Karang Gayam dan Bluuran ini bukan pertama kali. Bentrok sama pernah pecah pada Kamis, 29 Desember 2011. Bentrokan ini berujung pada pengusiran jamaah Syiah di dua desa beda kecamatan ini. Konflik ini berlangsung hingga saat ini, meskipun tidak sampai muncul di permukaan. Apalagi ajaran Syiah menurut MUI Jatim mengeluarkan fatwa bahwa ajaran Syiah ini sesat. Fatwa ini sesuai dengan Keputusan No 01/SKF-MUI/JTM/I/2012 tentang larangan ajaran Syiah ini, dikeluarkan pada 21 Januari 2012. Untuk memperkuat fatwa MUI Jawa Timur, Gubernur Jawa Timur juga mengeluarkan Surat Keputusan (SK) nomor 55 Tahun 2012 tentang Pembinaan Kegiatan Keagamaan dan Pengawasan Aliran sesat di Jatim.

Pandangan tentang ajaran antara Sunni-Syiah yang berbeda ini mempengaruhi tingkah laku yang berbeda pula yang berdampak pada Komunikasi intra-religius antara pengikut Sunni dan Syiah di komunitas-komunitas, terutama yang ada di dua Kecamatan yang berseteru. Hal inilah yang menjadi fokus kajian pada studi ini, bagaimana konflik antara pengikut Sunni dan Syiah ini berdampak terhadap Komunikasi intra-religius kedua keyakinan yang berbeda ini dalam kehidupan sosial-budaya masyarakat yang selama ini telah hidup berdampingan di desa-desa yang terlibat konflik. Bagaimana konflik dua keyakinan dalam ajaran Islam ini telah berdampak pada kondisi komunikasi antar-religius di Sampang Madura? Untuk itulah studi ini dilakukan guna memahami akar persoalan konflik dan upaya-upaya yang telah dilakukan oleh pihak-pihak komunitas lokal dan pemerintah lokal serta institusi terkait terhadap persoalan Sunni-Syiah di wilayah tersebut.

Dengan berbagai persoalan terkait dengan konflik intra-religius Sunni-Syiah yang terjadi di Sampang, Madura, maka perlunya untuk mengetahui akar-permasalahan dan hal-hal terkait pandangan, persepsi, dan upaya-upaya yang telah dan sedang dilakukan oleh para pemangku kepentingan pada komunitaskomunitas yang berkonflik yakni Muslim Sunni dan Syiah di Kecamatan Omben dan Karang Penang, Sampang terkait dengan esensi dan persoalan terkait ajaran Sunni dan Syiah yang selama ini telah dijalankan di daerah tersebut, untuk kemudian melihat dampak yang terjadi terhadap komunikasi intra-religius di daerah berkonflik.

Untuk itulah penelitian ini mengajukan rumusan masalah: kepentingan dan pandangan apa saja bagi warga pengikut ajaran Sunni dan Syiah di Sampang? Bagaimana pola konflik intra-religius SunniSyiah yang meliputi: jenis, tingkat perkembangan, persebaran, pelaku, isu-isu keagamaan yang terlibat dan dampak yang ditimbulkan? Bagaimana selama ini peran kyai sebagai tokoh agama yang dirujuk oleh masyarakat setempat, aparat desa, tokoh masyarakat, warga dan LSM lokal terlibat dalam penyelesaian konflik intra-religius Sunni-Syiah di Sampang? Bagaimana dampak dari konflik SunniSyiah yang terjadi terhadap Komunikasi intra-religius antara dua pengikut yang berbeda ini dalam proses penyelesaian konflik?

\section{Metode Penelitian}

Untuk mendapatkan data dan informasi yang empiris, maka penelitian ini menggunakan dua pendekatan. Pendekatan pertama menggunakan pendekatan sosio-kultural historis untuk 
mengidentifikasi ajaran apa saja yang pada umumnya berlaku di lingkungan masyarakat di desa Karang Gayam kecamatan Omben dan Desa Bluuran Kecamatan Karang Penang Kabupaten Sampang, dipersepsikan sebagai pedoman untuk berlaku dan memang dianggap seharusnya menguasai perilaku. Pendekatan ini juga dilakukan melalui pengamatan pada tindakan-tindakan manusia dan informasi mengenai perilaku secara umum untuk melihat seberapa jauh norma-norma masyarakat lokal dalam penyelesaian konflik dan upaya-upaya yang dilakukan untuk menjaga tatanan sosial berkaitan dengan kehidupan sosial-budaya komunitas Sunni dan Syiah. Pendekatan kedua, menggunakan pendekatan komunikasi antar budaya untuk mengamati perilaku Komunikasi yang selama ini telah berjalan dan dilakukan, serta aktifitas komunikasi antar budaya (antar-agama) yang menjadi bagian dari kehidupan sehari-hari komunitas Sunni dan Syiah di wilayah yang diteliti.

Lokasi penelitian ditentukan secara purposive di desa Karang Gayam Kecamatan Omben dan Desa Bluuran Kecamatan Karang Penang Kabupaten Sampang Penelitian juga dilakukan di tempat pengungsian warga Syiah di Rumah Susun Puspa Agro, Jemundo, Sidoarjo. Teknik pengumpulan data dan informasi dari para informan dilakukan dengan wawancara mendalam dan juga observasi langsung peneliti di desa Karang Gayam dan Bluuran, serta di tempat pengungsian warga Syiah di Rumah Susun Puspa Agro, Jemundo, Sidoarjo. Data yang terkumpul dianalisis dengan analisis naratif dan kajian sosio-kultural historis berdasarkan pernyataan informan yang terdiri dari warga penganut Sunni, warga penganut Syiah, kyai lokal, tokoh agama lokal, dan pihak-pihak yang terlibat dalam konflik ini.

\section{Hasil dan Pembahasan}

\section{Kepentingan dan pandangan warga pengikut ajaran Sunni dan Syiah di Sampang}

Dalam setiap kejadian konflik, seringkali kedua pihak yang berseteru mempunyai persepsi dan kepercayaan terhadap realitas dan isu-isu yang menjadi pemicu terjadinya konflik diantara pihak yang berseteru. Persepsi dan pandangan yang berbeda terhadap isu pada akhirnya menjadikan konflik semakin memanas dan ekskalasi konflik menjadi semakin tinggi. Ketegangan yang muncul dipicu oleh adanya persepsi dan kepentingan yang berbeda semakin membuat konflik tidak mampu diselesaikan.

Di sisi lain, isu yang tersebar di masyarakat sekitar dan luas juga memberikan versi-versi yang berbeda tentang akar masalah dan penyebab konflik itu sendiri. Ditambah lagi, peran media massa lokal dan nasional, menjadikan konflik semakin tidak tentu arah dan simpang siur. Hal ini pula yang terjadi dalam konflik yang melibatkan komunitas Syiah dan kelompok-kelompok Sunni di Sampang yang telah meregang hubungannya sejak konflik yang terjadi pertama kali di tahun 2005-2006. Eskalasi konflik terjadi pada tahun 2012 yang kemudian mengakibatkan pembakaran dan pengungsian komunitas Syiah sebagai komunitas minoritas di Sampang untuk keluar dari Kabupaten Sampang.

Studi ini mencoba untuk memahami akar permasalahan konflik, terutama kepentingan dan pandangan serta persepsi kedua kelompok yang berkonflik yakni dari komunitas Sunni di Kecamatan Omben, Sampang, dan komunitas Syiah dari dua desa yakni: Karang Gayam dan Blu'uran yang menjadi pengungsi dan saat penelitian ini dilakukan masih menempati rumah susun Jemundo di Sidoarjo.

Studi ini perspektif dari kedua belah pihak penting untuk dipahami guna melihat realitas sosial yang terjadi sehingga tidak terjadi ketimpangan informasi dan objektifitas dalam penanganan penyelesaian konflik. Studi ini tidak akan memberikan porsi lebih kepada salah satu pihak yang berkonflik sehingga upaya untuk merumuskan model forum komunikasi dalam penyelesaian konflik ini nantinya bisa terpenuhi. Hal inilah yang seringkali menjadi problem dalam studi-studi konflik yang sudah dilakukan. Seringkali studi yang dilakukan tidak melakukan penggalian data kepada semua pihakpihak yang terlibat dalam perseteruan melainkan kepada salah satu pihak saja sehingga penyelesaian konflik (conflict resolution) tidak mampu dilakukan secara maksimal dan berat sebelah. Sebaliknya studi-studi lainnya juga dilakukan untuk kepentingan tertentu, pemberi dana, pihak pemerintah, 
maupun untuk tujuan gerakan politik, sehingga sudut pandang dalam mengungkap fenomena yang diteliti menjadi lebih subjektif dan disesuaikan dengan kepentingan-kepentingan yang ada.

Ketika penelitian ini dilakukan, beberapa warga Sunni yang ditemui di desa Karang Gayam dan Bluuran, Kecamatan Omben, Sampang Madura enggan untuk menyampaikan pandangan mereka terhadap persoalan konflik Sunni-Syiah yang terjadi di daerah mereka. Namun dengan pendekatan yang dilakukan ke beberapa rumah penduduk, diantara komunitas Sunni memberikan tanggapan, pandangan, dan persepsi mereka terhadap konflik yang ada.

Secara umum jika melihat kehidupan masyarakat di kedua desa konflik ini sepertinya tidak ada gejolak yang berarti. Terutama pada masyarakat yang tinggal di dekat jalan raya utama. Penduduk di daerah ini hidup seperti kondisi keseharian yang mereka lakukan. Hal ini mengingat dusun Nangkernang, tempat komunitas Syiah pimpinan Kyai Tajul Muluk yang dibakar oleh massa berada di lokasi yang jauh dan remote dari kehidupan masyarakat kebanyakan di pinggir jalan raya. Bahkan petugas Brimob yang berjaga di pos keamanan penempatan mereka juga tidak melakukan aktifitas apapun, selain monitoring rutin ke wilayah dusu yang terbakar.

Dusun Nangkernang pun sepi dan tidak ada aktifitas manusia yang berarti karena penghuninya berada di Rusun Jemundo, Sidoarjo. Kondisi tanah yang licin jika hujan, dan jalan yang tidak memungkinkan mobil untuk masuk, menjadikan daerah bekas konflik ini semakin terpencil.

Warga Sunni yang tinggal di sekitar daerah dekat dengan wilayah konflik pun tetap menjalankan aktifitas keseharian mereka. Bahkan beberapa keluarga Sunni yang ada mempunyai anggota keluarga dan masih menjadi saudara dari komunitas Syiah yang menjadi pengungsi di Jemundo, Sidoarjo. Mereka menceritakan bahwa sebenarnya konflik antara Sunni-Syiah yang terjadi di tempat mereka ada yang menganggap sebagai perbedaan 'ideologis' berkaitan dengan substansi kepercayaan (belief) yang dilimiliki pengikut Syiah. Kedua, juga karena perbedaan 'kultural,' terkait dengan tata cara melaksanakan kegiatan atau tradisi yang dilakukan oleh Syiah yang dianggap berbeda oleh pengikut Islam Sunni. Seperti penuturan berikut:

Syiah itu pengakuannya beda, tidak mengakui Nabi Muhammad tapi Sayidina Ali. Syiah di Bluuran ini beda dengan Syiah yang ada, karena tidak mengakui khalifah, itu juga menurut MUI [...] Penganutnya di sini di pinggiran [...] Pengakuan Tajul (Muluk) bahwa itu Syiah, setelah di cross check [sic.] ke MUI...bukan Syiah tapi aliran sesat. (Faturossi, warga Desa Bluuran)

Orang Syiah beda dengan orang Sunni...Kalo orang Sunni pengajiannya setiap minggu digilir di rumah penduduk [...] Ramadan beda, karena buka puasanya beda. Orang Syiah buka puasanya lama, tidak waktu Maghrib (Maftuha, warga Karang Gayam)

Perbedaan Syiah menurut pengikut Sunni adalah karena orang-orang Syiah lebih mengagungkan Ali bin Abi-Thalib yang merupakan menantu Nabi Muhammad SAW, sebagai khalifah pengganti Muhammad. Mereka dianggap oleh pengikut Sunni tidak mempercayai sahabat-sahabat Nabi yang lain seperti Abu Bakar, Utsman bin-Affan, dan Umar bin-Khatab. Inilah yang membuat orang-orang Sunni merasa bahwa pengikut Syiah mengkhianati kebenaran Islam.

Menurut warga Sunni di desa Bluuran dan Karang Gayam dianggap sudah melenceng dari ajaran agama Islam yang benar menurut pengikut Sunni. Seperti yang dituturkan oleh Faturossi, pengikut Syiah di Bluuran tidak seperti Syiah yang sebenarnya. Misalnya, warga Syiah di Bluuran melanggar Rukun Iman yang dipercaya oleh orang Sunni. Menurut warga ini orang Syiah setelah percaya pada Allah, mereka percaya pada Sayyidina Ali, bukan Rasulullah Muhammad.

Di kalangan orang Syiah, menurut Faturossi, memiliki kitab suci Al-Qur'an yang ayat-ayatnya lebih banyak daripada Al-Qur'an yang digunakan orang Sunni. Walaupun ketika peneliti menanyakan apakah Faturossi melihat sendiri kitab Al-Qur'an yang digunakan orang Syiah, dia menyatakan belum pernah. Hampir sama dengan Faturossi, beberapa warga Sunni yang ditemui di Desa Bluuran dan Karang Gayam memang mempunyai kesamaan pandangan, penilaian, dan persepsi terhadap warga 
Syiah yang ada di desanya. Walaupun sebagian besar di antara mereka tidak mengetahui sendiri, namun stigma terhadap penganut Syiah di desa itu beredar dari mulut ke mulut yang menyebabkan pandangan dan cerita/naratif warga Sunni terhadap pengikut Syiah sama.

Selain persoalan kepercayaan mahzab, menurut warga Sunni, pengikut Syiah juga melakukan beberapa ritual ibadah dan tradisi yang berbeda. Beberapa perbedaan yang dihimpun dari pendapat para warga Sunni yang ditemui di dua desa, hal-hal berikut ini yang bagi warga Sunni dilakukan oleh pengikut Syiah di desanya, yang kemudian dilekatkan oleh warga Sunni sebagai "ciri-ciri" identitas Syiah: Pertama, gaya bicara pengikut Syiah lebih sombong, atau istilah warga Sunni "gaya bahasanya tinggi," misalnya, untuk urusan perkawinan, pengikut Syiah jika tidak dikawinkan oleh orang Syiah, maka dianggap anaknya (hasil pernikahan) dianggap kafir. Kedua, orang Syiah melakukan kawin kontrak (Mut'ah). Ketiga, orang Syiah menjelek-jelekan Khalifah Abu Bakar, Umar, dan Ustman.

Ciri-ciri identitas pengikut Syiah yang distigmakan oleh masyarakat di desa ini telah berlangsung lama, sehingga perbedaan di antara pengikut Sunni-Syiah semakin menguat. Terlebih, pengikut Syiah dianggap menjalankan tata cara ibadah yang berbeda seperti ketika sholat tidak bersedekap, melainkan tangannya lurus ke bawah. Dalam menjalankan ibadah puasa Ramadan juga terdapat perbedaan keyakinan waktu berbuka puasa, serta mengadakan acara Maulid Nabi yang dianggap berbeda dari tradisi warga Sunni yang selalu mengadakan perayaan Maulid di rumah masing-masing, warga Syiah merayakannya secara bersama di masjid mereka sendiri.

Akan halnya pendapat warga tentang Syiah yang dianut oleh pengikut Ustadz Tajul Muluk, tokoh agama yang menyebarkan Islam Syiah kepada masyarakat di desa Bluuran dan Karang Gayam, dianggap oleh warga Sunni tidak mengajarkan Syiah seperti yang dilakukan oleh pengikut Islam Syiah di luar Sampang, Madura. Melainkan, Tajul Muluk dianggap mengajarkan aliran sesat. Tajul Muluk, menurut warga Sunni, mengajarkan ajarannya dengan berdakwah dari rumah ke rumah terus ke pengajian umum. Setelah mondok di YAPI Bangil Tajul Muluk pergi belajar Islam di Iran. Sepulangnya ke Sampang, Tajul langsung mengajarkan Syiah kepada warga di sana. Oleh karena penduduk desa yang miskin, dan mereka menjalankan agama "Islam kultural" (istilah yang disampaikan oleh Faturossi, warga desa Bluuran) atau dalam bahasa Madura "Rok-Norok" yang artinya ikut-ikutan. Maka dengan mudah ajaran Syiah Tajul Muluk diikuti oleh warga desa yang dipengaruhi oleh dakwah Tajul Muluk.

Warga Sunni di Sampang sendiri sebenarnya tidak mengakui apa yang dilakukan oleh para pengikut Syiah di daerahnya karena ajaran yang mereka lakukan sebenarnya bukanlah ajaran Syiah yang menurut mereka "benar" seperti yang dikatakan oleh MUI Jawa Timur dan pusat. Warga Sunni di Sampang tahunya bahwa ajaran Syiah yang dilakukan oleh warga Bluuran dan Karang Gayam itu bukan Syiah. Melainkan ajaran sesat ustadz Tajul Muluk. Tuduhan semacam ini yang kemudian berkembang bahwa Ustadz Tajul Muluk mengajarkan sekte tertentu yang mengatas-namakan Syiah. Ditambah lagi dengan pandangan para kyai dan ustadz lokal yang dipercaya oleh pengikut Sunni di Sampang, bahwa Tajul Muluk sudah melakukan dakwah sesat kepada warga Sunni. Mereka menuntut pengikut Tajul Muluk untuk bertobat dan kembali ke ajaran Sunni. Jika mereka bertobat, maka mereka boleh kembali ke desanya dan membangun rumah-rumah mereka kembali dan memiliki ladang yang mereka butuhkan.

Dalam wawancara yang dilakukan oleh peneliti dengan para pengungsi Syiah di Rusun Puspa Agro, Jemundo, Sidoarjo, apa yang dikatakan oleh para pengikut Sunni tentang Syiah dibantahkan semuanya. Pengikut Syiah merasa bahwa mereka tetaplah ornag yang beragama Islam. Mereka bukan kafir dan mereka bukanlah pemeluk aliran sesat seperti yang dituduhkan oleh orang-orang Sunni di daerah mereka di Sampang. Pengikut Syiah percaya bahwa apa yang mereka yakini adalah benar.

Pengikut Syiah ini menyatakan bahwa perbedaan ideologi dalam beragama itu biasa. Jika Syiah percaya kepada keluarga Nabi Muhammad daripada sahabat Nabi itu sebenarnya bukan persoalan utamanya. Para pengikut Syiah yang diwawancarai dalam penelitian ini mengatakan bahwa mereka 
pernah menghina sahabat Nabi seperti Abu Bakar, Utsman, dan Umar. Namun mereka lebih menghargai Ali.

Kalau persoalan perbedaan ideologi kan boleh. Ada banyak Imam dengan masing-masing ajarannya. Kalau kami mempercayai pada imam tertentu kan tidak masalah. [...] Di Islam, banyak kitab yang digunakan oleh para ulama tentang ajaran Islam. Kalau kita menggunakan kitab yang berbeda karena keyakinan aqidah masing-masing kan sebenarnya tidak masalah. Kita [syiah] tidak menjelek-jelekan sahabat [Rosulullah] tapi kita lebih percaya sama Nabi Muhammad dan keluarganya. Itu yang dipilih Allah [...] Ideologi syiah, dalam syiah keluarga nabi Muhammad yang kita taati. Tapi, seolah-olah kita anti kepada sahabat. Orang syiah tetap mengetahui Abu Bakar. Yang dipilih oleh Allah itu kan yang harus diyakini. Tapi Abu Bakar diangkat oleh manusia. Ali diangkat oleh Rosulullah. Keimanan kami sama. Masalah ideologi dalam hal fiqih. 4 imam...Berbeda soal sedekap ketika sholat, tidak ada yang punya pikiran sama. Kita lebih percaya kepada imam Maliki kalo sholat tidak perlu sedekap. Kita syiah difitnah ngaji koran, bukan Al-Quran (Zaini, pengikut Syiah, usia 25 tahun)

Awal perkenalan dengan Syiah sebenarnya di keluarga saya terjadi ketika ayah saya membawa foto Khomaeni. Ini apa? Waktu itu saya juga belum ngerti. [...] sebenarnya [syiah] itu ya Islam. Kami menjalankan agama Islam. Tidak ada bedanya dengan Sunni. Tapi kan masyarakat itu tidak bisa menerima. Kami percaya dengan agama yang kami lakukan. Yang diajarkan oleh Adik saya (Tajul Muluk) bukan aliran sesat, ya Syiah itu yang sesuai ajaran (Ustadz Iklil, Ketua pengungsi Syiah)

Apanya yang harus tobat? Kami kok disuruh tobat... Kita kan sudah membaca kalimat Shahadat, tiada Tuhan selain Allah dan Muhammad Rosul Allah. Apalagi yang harus kita lakukan?...Kalau kita disuruh pindah agama (ke Sunni) kan kita sudah Islam? (Ummi, warga pengungsi Syiah usia 38 tahun).

Dari pengakuan pengikut Syiah tersebut bisa dilihat sebenarnya perbedaan keyakinan di antara kaum Sunni dan Syiah mengenai imam yang mereka rujuk dan yakini. Persoalan sejarah ke-khalifaan setelah Nabi Muhammad wafat, yakni dengan dipilihnya pengganti beliau kepada Abu Bakar, menjadi awal dari perseteruan politik di dalam Islam. Sementara, Ali bin Abi Thalib, anak menantu Nabi Muhammad-lah yang dianggap oleh para pengikuti Syiah sebagai pihak yang berhak, karena keluarga Ali-lah yang dilindungi dan dideklarasikan sebagai 'Ahlul Bayt' atau orang-orang terpilih oleh Nabi Muhammad sendiri kepada Allah SWT.

Perbedaan ideologis bagi pengikut Syiah adalah perbedaan yang harus dihormati. Dengan kata lain, di dalam Islam banyak imam yang mengajarkan ajaran Fiqih yang berbeda-beda dengan kitabnya masing-masing. Kalau pengikut Sunni percaya pada imam-imam mereka, maka pengikut Syiah pun merasa benar dengan mengikuti imam-imam yang mereka yakini kebenaran ajarannya. Perbedaan ideologis dalam menjalankan agama bagi pengikut Syiah harus dihormati, karena perbedaan itu adalah persoalan keyakinan.

Para pengikut Syiah sendiri merasa selama ini guru-guru mereka dan ulama mereka tidak mengajarkan aliran agama yang menyimpang. Itulah sebabnya para pengikut Syiah tidak bersedia jika harus dipaksa untuk "pindah agama" atau melakukan tobat dengan memeluk Islam Sunni. Bagi mereka, Syiah yang mereka jalani adalah 'agama Islam.' Mereka sudah menjalankan semua ritual Islam, bahkan mereka menganggap tidak ada perbedaannya. Penolakan pengikut Syiah terhadap paksaan untuk "pindah agama" ke Sunni ini dianggap penghinaan. Dengan nada yang tegas, para pengikut Syiah menyatakan penolakan untuk disuruh pindah agama.

Untuk apa kita pindah agama? Kita ini Islam. Kita membaca kalimat Syahadat setiap hari, sama dengan mereka [Sunni]. Kita juga sholat, sama dengan mereka. Kok kita difitnah katanya tidak Islam, sholatnya di jama'. Kalo kita pergi ya..sholatnya dijama'. Kalo tidak ya..kita tetap sholat di masjid (Ummi, warga pengungsi Syiah, 38 tahun).

Kenapa kok kita harus pindah agama? Kita tidak murtad. Kalo disuruh baca kalimat Syahadat, kita sudah ucapkan dari dulu. Agama kita ya Islam. Kalau kita murtad, baru kita harus baca Syahadat lagi [...] kalo kita sholat tangannya tidak sedekap itu yang benar, karena aliran darah bisa langsung, kan bagus itu (Siti, warga pengungsi Syiah usia 50 tahun) 
Memang persepsi yang muncul dalam konflik Sunni-Syiah salah satunya juga karena para pengikut Syiah ini dianggap 'kafir' atau 'murtad' oleh para kyai dan ustadz serta pengikut Sunni di Sampang Madura. Oleh karena itu para ulama di Sampang dan komunitas Sunni di sana meminta warga Syiah untuk kembali memeluk agama Islam Sunni, barulah mereka diperbolehkan pulang Namun para pengikut Syiah tidak bersedia untuk melakukan 'tobat' karena mereka tidak murtad seperti yang dituduhkan oleh kelompok Sunni.

Perbedaan prinsip semacam ini juga menyulitkan upaya-upaya atau jalan damai yang ditempuh untuk menyatukan pengikut Sunni dan Syiah di Sampang Madura. Selama persepsi dan keyakinan ini kukuh dimiliki oleh kedua pengikut ini, maka selama itu pula, kedua kelompok ini akan terus bersitegang. Keyakinan (belief) dianggap sebagai ideologi yang menjiwai keimanan mereka terhadap agama yang mereka peluk. Sehingga akan sulit untuk dirubah. Meskipun sebenarnya para pengikut Syiah, seperti kebanyakan pengikut Syiah di tanah air, menjalankan "taqiyah" yakni menyembunyikan identitasnya sebagai Muslim Syiah ketika melakukan interaksi dengan para pengikut Sunni di masyarakat. Bahkan imam-imam Syiah pun banyak juga yang menjadi imam di masjid-masjid Sunni.

Tidak hanya persoalan membaca kalimat Shahadat dan sholat lima waktu. Soal tata cara menjalankan ibadah sholat pun menjadi sumber permasalahan konflik. Seperti dijelaskan sebelumnya, menurut kelompok masyarakat Sunni di Sampang, orang-orang Syiah jika sholat tidak pernah sedekap. Sholatnya ditambahi gerakan-gerakan yang dianggap oleh kaum Sunni "tidak sah" dikerjakan. Ketika peneliti mengunjungi pengungsi Syiah di Rusun Puspa Agro, Jemundo, Sidoarjo, peneliti melihat tata cara pengikut Syiah yang sedang menjalankan Sholat Maghrib di kalangan ibu-ibu secara berjamaah di lantai 2 Rusun tersebut. Tidak ada laki-laki yang menjadi imam maupun makmum di sholat jamaah tersebut. Beberapa gerakan dalam sholat yang tidak biasa dilakukan oleh pengikut Sunni dilakukan oleh pengikut Syiah, seperti tidak meletakkan kedua tangan di dada dan juga mengangkat tangan untuk takbir berkali-kali ketika jamaah duduk sujud akhir sebelum mengucapkan salam yang terakhir. Tata cara ritualisme yang dilakukan ini yang juga memicu perbedaan persepsi pada warga Sunni dan meminta pengikut Syiah untuk kembali kepada ajaran Islam yang benar menurut Sunni.

Selain itu, menurut orang Sunni, orang-orang Syiah juga melakukan sholat lima waktu yang sering dijamak. Persepsi-persepsi ini dibantah oleh kelompok Syiah. Mereka melakukan itu semua karena mereka lebih menghargai makna agama Islam yang diyakininya. Begitu pula, menurut kaum Sunni, kitab Al-Qur'an kelompok Syiah berbeda dengan Sunni. Menurut orang Syiah, kitab Al-Qur'an mereka sama dengan kitab yang dibaca orang Sunni.

Pengikut Syiah juga mengaku melakukan ritual yang sama dilakukan orang Sunni. Mereka juga puasa Ramadhan Mereka juga melakukan pengajian rutin seperti Fatayat dan Muslimahan yang menjadi tradisi NU (Sunni). Mereka juga mempunyai acara Diba'an dan aulidan. Namun, persepsi yang dimiliki kaum Sunni, bahwa tata cara puasa, diba'an, dan Maulidan yang dilakukan oleh warga Syiah berbeda. Walaupun orang-orang Sunni di Sampang sendiri tidak melihat secara langsung, tapi dari "katanya." Ketika dikonfirmasi kepada warga pengungsi Syiah akan hal-hal ini, mereka membantah apa yang dituduhkan kepada mereka:

Kalau kita sholat Jama' kan karena kita bepergian. Kalau bepergian kan harus di jama' sholatnya [...] apalagi kawin kontrak, apa itu kawin kontrak? Kita nggak tahu kawin kontrak. Kalau poligami, ya kita harus percaya karena itu ada di kitab Al-Qur'an...nggak ada kawin kontrak. [...] Kalau buka puasa kita lebih lama, karena ya kita menghargai ibadah dulu, kita sholat dulu, baru buka puasa. Tidak ada menunggu sampai malam [...] Kita Maulidan kalau menurut Ustadz Tajul dilaksanakan di Masjid tidak di rumah. Itulah yang Kyai-kyai orang Sunni tidak suka karena kehilangan rejeki itu kyai-kyainya (Umi K, warga pengungsi Syiah, usia 38 tahun)

Syiah itu lebih benar. Karena fiqih dan akidahnya benar. Misalnya sholat tidak bersedekap lebih baik. Juga dengan sholat Syiah lebih khusyu'. Orang Madura tidak tahu tentang kawin kontrak. Mereka tidak diterima oleh orang-orang yang di Karang Gayam (Rohma, warga pengungsi Syiah, usia 20 tahun) 
Menurut pengakuan pengungsi Syiah, sebenarnya masyarakat di desa mereka dipengaruhi oleh "provokator" yakni para kyai dan ustadz yang menurut mereka merasa kehilangan rejeki, yakni pemberian amplop dari warga ketika masa Maulid Nabi. Ustadz Tajul lah yang menyarankan dan mengajak warga Syiah yang miskin untuk merayakan secara bersama di masjid, sehingga tidak memberatkan keluarga untuk khusus mengadakan acara yang menghabiskan uang. Hal-hal inilah yang dianggap oleh orang Syiah, memicu kemarahan kyai dan ustadz Sunni, sehingga mereka mempengaruhi orang-orang Sunni untuk menyerang orang-orang Syiah yang dianggap pengikut aliran sesat Ustadz Tajul Muluk.

Ada tradisi yang dilakukan oleh warga di desa-desa tempat bermukim warga Sunni dan Syiah di Sampang, jika Maulid Nabi tiba, mereka mengadakan acara syukuran yang dilakukan oleh masingmasing rumah tangga. Tradisi yang terkenal dengan nama "cocok" adalah kebiasaan masyarakat selama sebulan dalam rangka Maulid Nabi dengan memberikan kue dan nasi kepada tetangganya. Menurut penuturan warga pengungsi Syiah, warga Sunni di desanya tidak mau menerima pemberian nasi dan kue yang diberikan oleh warga Syiah pada acara Maulid Nabi karena makanan warga Syiah dianggap haram. Bahkan nasi yang diberikan oleh warga Syiah dibuang. Jika nasi itu dimakan oleh ayam, maka ayam tadi tidak boleh disembelih untuk dimakan, karena ayam tadi sudah memakan nasi haram milik warga Syiah. Stigma ini melekat pada warga Sunni karena dakwah yang dilakukan oleh Ustadz dan Kyai mereka dengan menuduh warga Syiah adalah kafir dan tidak beriman. Mereka bukan Islam. Oleh karenanya mereka harus dijauhi karena dianggap "mengotori" agama Islam. "Shia itu najis, takut haram. Kalo ada orang mati orang syiah datang dianggap najis dan haram...makanya harus dibersihkan tempatnya kalau kita datang bertamu ke rumah orang Sunni," demikian pengakuan Ummi Khulsum, warga Syiah.

Warga Syiah sendiri melihat hal semacam ini keterlaluan. Mereka sebaliknya bersikap menerima warga Sunni dengan baik. Bahkan jika mereka akan melakukan pengajian bersama, warga Syiah tidak mempermasalahkan. Seringkali yang sulit untuk berdamai, menurut warga pengungsi Syiah, adalah pengikut Sunni sendiri. Walaupun sebenarnya mereka tahu tidak semua pengikut Sunni di desanya yang menolak kehadiran pengikut Syiah di Sampang. Ini terbukti dengan beberapa orang tua yang memasukkan anak-anaknya ke pesantren Syiah untuk mengaji dan belajar tentang Islam. "Menjadi syiah karena menemukan ada yang lebih tinggi lagi ilmunya...menjadi syiah karena kesadaran...setelah terbuka wawasan. Orang pergi ke pesantren syiah karena disuruh orang tuanya," (Anna, warga pengungsi Syiah, usia 23 tahun).

Perbedaan-perbedaan penafsiran terhadap persoalan kekhalifahan setelah Nabi Muhammad wafat membuat pengikut ajaran Islam di dunia ini mempunyai keyakinan dan persepsi ideologis yang berbeda. Perbedaan yang juga dipicu oleh penafsiran terhadap sejarah dan peristiwa serta penafsiran pada ayat-ayat tertentu dalam kitab Al-Qur'an memunculkan perbedaan cara-cara dakwah dan pengajaran yang dilakukan oleh para Imam setelah masa wafatnya Nabi Muhammad. Ini yang terbawa hingga kini pada penganut Islam Sunni dan Syiah. Sementara itu, dalam konteks kasus warga di Kecamatan Omben, Sampang Madura, ketidak-tahuan, sekolah rendah, dan kemiskinan yang mereka hadapi membuat mereka pasrah dan mengikuti saja dengan mudah setiap ajaran agama yang diberikan kepada orang-orang yang dianggap mempunyai ilmu agama lebih tinggi dibanding mereka. Sehingga apa yang diyakini benar oleh para pengikut Sunni maupun Syiah di sana, mengikuti saja apa yang dianggap dan diyakini benar oleh para tokoh agama, seperti ustadz dan kyai masing-masing tanpa dicerna dan dipelajari lebih dalam. Hal semacam ini yang berbahaya bagi kehidupan beragama masyarakat di Indonesia yang memegang konservatisme dan fundamentalisme yang bukan karena usaha pencarian ilmu yang mereka lakukan sendiri, melainkan mengikuti ajaran yang disampaikan oleh tokoh-tokoh agama lokal di lingkungan mereka yang mereka yakini lebih tinggi ilmu agama Islamnya dibandingkan mereka. Menjadi krusial, ketika para tokoh agama ini "bermain" dengan kepentingannya sendiri dan memprovokasi serta berdakwah sebagai upaya untuk menyebar kebencian atau balas dendam atau menjatuhkan lawan-lawannya melalui dakwah-dakwah keagamaan. Agama tidak lagi digunakan untuk kepentingan akherat, melainkan untuk kepentingan "politik" duniawi. 


\section{Akar dan pola konflik Sunni-Syiah Sampang}

Seperti yang ditulis oleh John T. Sidel (2008) bahwa untuk melihat persoalan konflik/kekerasan antar agama (inter-religius violence), maka perlu dijelaskan dalam konteks kejadian waktu tertentu, lokasi, para pelaku yang terlibat, target-target kekerasan, bentuk-bentuknya, dan proses-proses mobilisasi yang diasosiasikan dengan fase kekerasan/konflik agama di Indonesia. Sidel juga mengatakan bahwa terjadi pergeseran paradigma kekerasan/konflik inter-religius yang terjadi di Indonesia dari konflik komunal agama (religius riots) tahun 1995-1997 kepada peristiwa kekerasan masal agama (religius pogrom) tahun 1998-2001 dan gerakan-gerakan jihad sejak tahun 2000 hingga saat ini (Sidel 2008:29). Oleh karena itu penting bagi Sidel untuk melihat kunci-kunci seperti yang telah disebutnya yakni: "particular timing, location, perpetrators, targets, forms, and processes of mobilization associated [...]," (Sidel 2008:29).

Kedatangan ajaran Islam Syiah sendiri di kecamatan Omben, Sampang dimulai ketika KH. Makmun sekitar tahun 1980an menerima tamu, yakni sahabatnya sendiri yang baru datang dari Iran. Dengan membawa gambar Ayatollah Khomaeni, pemimpin revolusi Iran tahun 1979. Cerita kawannya ini membuat KH Makmun tertarik untuk belajar Syiah lebih lanjut. Dengan datang ke Pesantren YAPI di Bangil, KH. Makmun mendapatkan banyak ilmu tentang ajaran Syiah. Dia pun lalu memasukkan ketiga anaknya yakni, Iklil Al-Milal, Tajul Muluk, dan Roisul Hukama ke pondok pesantren YAPI di Bangil, sebagai pusat ajaran Syiah di Jawa Timur, untuk belajar lebih dalam tentang Syiah. KH. Makmun memilik 8 orang anak, dan tidak semuanya pemeluk Syiah. Bahkan istrinya pun, masih memeluk Islam Sunni, karena keluarga besarnya adalah penganut Sunni. Ketika ditemui di tempat pengungsian Rusun Jemundo, istri KH. Makmun tinggal bersama anak perempuannya yang turut sebagai pengungsi. Ibu ini ikut mengungsi sebagai bentuk toleransi dia terhadap tiga orang anaknya yang diusir oleh warga Sampang, dan juga karena sayangnya terhadap cucu-cucunya dari Tajul, Iklil dan Hanni. Ibu ini dulunya tinggal dengan Roisul di Bluuran sana. Namun, setelah konflik antara Roisul dan kakaknya, dia memilih untuk tinggal dengan Tajul Muluk.

Adapun cerita tentang bagaimana KH Makmun mengenal ajaran Syiah dan kemudian melakukan pengajaran dan dakwah kepada masyarakat di sekitarnya dan kemudian menjadi penyebaran Syiah di daerah Sampang, ada perbedaan versi masing-masing.

Awalnya, abah saya itu dari Arab... saya masih ingat, waktu saya kelas 4 SD, ada gambar orang pakai sorban, saya tidak tahu itu apa... barulah saya tahu setelah besar...itu adalah Khomeni. Saya juga baca kitab dari abah saya... waktu itu dapat buku, kiriman, abah saya tiap satu tahun dapat kiriman buku, padahal abah saya tidak pernah ke Iran, ke mana... setelah revolusi Iran, abah saya berpikir, siapa ini orang? orang kok bisa hebat memenangkan revolusi...baru dipelajari siapa Khomeini itu Syiah melawan Sunnah...dari situ abah saya belajar. Tahun 1997 saya dan Dik tajul dikirim ke YAPI Bangil..Adik saya lalu pergi ke Arab. Lalu saya mondok di Kyai Alawi Sampang. Lha kenapa saya ke Syiah, karena akhirnya saya tahu, kok keluarganya Nabi, cucunya dipotong-potong. (Peristiwa perang Karbala, ketika Husen, cucu Nabi dibantai oleh kaum Sunni).... lha dari situ saya beralih ke Syiah (Ustadz Iklil, pemimpin pengungsi Syiah Sampang).

Menurut tokoh agama formal di Sampang menceritakan dengan versi yang berbeda seperti yang diceritakan oleh istri KH. Makmun di atas dan salah satu anaknya, yakni Ustadz Ikll Al-Milal. Salah satu versi yang dijelaskan oleh KH Faidol Mubarak, wakil dewan Suriah NU Sampang, bahwa kedatangan Syiah di daerahnya adalah dari sembunyi-sembunyi penyebaran kitab-kitab orang Syiah yang dibawa oleh KH. Makmun yang kala itu baru pulang dari Mekkah.

Perseteruan antara anak-anak KH. Makmun terjadi setelah Tajul Muluk pulang dari menimba ilmu di Arab dan YAPI Bangil. Menurut istri KH. Makmun, ibu dari Tajul Muluk dan Roisul Hukama yang berseteru, menceritakan bahwa perseteruan kedua anaknya ini terjadi sudah sejak lama. Tidak hanya masalah perempuan seperti yang dilansir dalam pemberitaan media dan pendapat aparat, melainkan juga persoalan kedudukan mereka sebagai Ustadz di kampungnya. Tajul Muluk dan Roisul Hukama, keduanya awalnya sama-sama menjadi anggota Ikatan Jamaah Ahlul Bait Indonesia (IJABI), yang diketuai oleh Prof. Jalaluddin Rahmat dari Bandung. Bahkan Roisul waktu itu menjadi ketua IJABI 
cabang Sampang, Madura. Namun, karena perseteruan dengan kakaknya, dia mengundurkan diri dari IJABI dan memilih kembali menjadi Sunni. Sejak itulah konflik keduanya terus memanas. Setelah Roisul kembali memeluk Sunni, hanya tinggal 3 orang anak KH. Makmun yang memeluk Syiah yakni Iklil, Tajul, dan Hanni, salah satu anak perempuannya

Dakwah agama yang dibawa oleh Tajul Muluk dari pesantren YAPI dan dari Arab membawa perbedaan yang diyakini oleh masyarakat setempat yang telah lama menganut Sunni. Ditambah lagi dengan konflik antar pribadi yang terjadi pada Tajul dan Roisul karena alasan pribadi, seperti soal perempuan yang ingin dinikahi Roisul namun tidak diijinkan oleh Tajul. Tajul memilihkan perempuan tersebut dengan laki-laki lain yang kemudian dia nikahkan sendiri, membuat Roisul menjadi marah, demikian cerita dari Ibu dan istri Ustadz Tajul Muluk di rumah pengungsian mereka.

Isu adanya perselisihan antara Tajul Muluk dan Roisul Hukama terkait perempuan ini, dibantah oleh istri dan kakaknya, Iklil. Menurut mereka, bukan soal perempuan sebenarnya yang utama, tapi pesoalan "ekonomi" atau "rejeki" yang diperebutkan antar ustadz dan kyai lokal di daerahnya. Tambahan lagi, persetruan itu -antara kedua kakak-adik ini-juga dipicu persaingan "pengaruh" kekuatan mereka terhadap umat atau jamaah masing-masing di pesantren kecil dan masjid kecil mereka.

Pada saat yang lain, juga terjadi perseteruan antara Tajul dan Roisul perihal siapa yang menjadi pemimpin IJABI cabang Sampang yang diikuti keduanya. Tajul rupanya lebih agresif dalam menjalankan dakwah Syiah nya, sementara Roisul merasa dikalahkan oleh dakwah yang dilakukan kakaknya ini. Hingga akhirnya Roisul memilih untuk kembali ke Sunni dan berkonfrontasi dengan kakaknya. Roisul lalu mendekati ulama-ulama Sunni di daerahnya yang memang sejak awal tidak menyukai dakwah yang dilakukan oleh Tajul dengan ajaran Syiah-nya. Mereka bahkan menganggap apa yang dilakukan oleh Tajul bukan dakwah Syiah melainkan dakwah aliran seasat Tajul sendiri.

Perseturuan keluarga dan juga perbedaan pemahaman terhadap ajaran agama Islam antara Sunni dan Syiah menyulut aksi kekerasan yang dilakukan warga yang barangkali tidak tahu apa yang sebenarnya terjadi. Peneliti sendiri mendapati fakta bahwa warga Sunni sendiri yang berada di kedua desa yang berseteru sebenarnya tidak pernah tahu apa yang dilakukan oleh warga Syiah ketika beribadah dan keyakinan nilai-nilai agama yang dianutnya.

Mirip dengan kondisi ini, beberapa warga Syiah yang diwawancarai di tempat pengungsian, juga tidak benar-benar memahami perbedaan Sunni dan Syiah dan mengapa mereka menganut Sunni dan Syiah, kecuali perbedaan kepercayaan kepada Sayidina Ali, menantu Nabi Muhammad, yang lebih dihargai oleh penganut Syiah daripada 3 sahabat Nabi yang lain. Lebih dari itu, esensi agama Sunni dan Syiah sendiri tidak mereka pahami dengan baik, melainkan hanya karena percaya pada dakwah dan pengajaran yang dilakukan oleh ustadz-ustadz yang mereka ikuti dan hormati.

\section{Jenis, tingkat perkembangan, persebaran dan pelaku dalam konflik Sunni-Syiah Sampang}

Menurut Coloombijn dan Thomaslindblad (2002), untuk mengenal atau mendeskripsikan konflik di Indonesia setelah era rezim Orde Baru adalah dengan mengetahui beberapa kunci. Menurut mereka, kunci untuk memahami kekerasan yang terjadi di Indonesia setalah era Orde Baru adalah dengan membandingkannya dengan kasus-kasus kekerasan lainnya. Keduanya menuliskan kunci itu antara lain: pertama, membandingkan kasus kekerasan (inter/intra-religius dan etnik) dengan kasus-kasus kekerasan yang terjadi di Indonesia pada saat yang sama. Kedua, membandingkannya dengan kekerasan yang terjadi di negara lain. Ketiga, membandingkannya dengan peristiwa kekerasan/konflik pada masa lampau atau sebelumnya. Dengan perbandingan ini maka peneliti akan mampu mengungkap apa yang unik di setiap situasi-situasi tertentu dari peristiwa konflik/kekerasan dan apa yang umumnya terjadi di bawah kondisi yang sama (Coloombijn \& Thomaslinblad 2002: 5). 
Penelitian ini barangkali tidak mencoba untuk membandingkan apa yang terjadi antara Sunni-Syiah di Sampang Madura. Namun yang akan dilihat adalah bagaimana akar konflik yang dijelaskan pada bagian sebelumnya menjadi pemicu bagi konflik Sunni-Syiah yang lebih besar, yang pada akhirnya melibatkan pemerintah nasional dan negara dalam tataran ini. Konflik yang awalnya dikira dari perseteruan keluarga menjadi konflik politik Sunni-Syiah dalam konteks nasional. Diskursus SunniSyiah menjadi mencuat di tanah air, ketika sebelumnya (masa Orde Baru) persoalan identitas keagamaan Sunni dan Syiah ini tidak pernah dipertentangkan dan menjadi konflik yang massive. Bagian ini membahas lebih detail tentang jenis atau bentuk konflik Sunni-Syiah di Sampang, perkembangannya dan juga persebarannya di tingkat lokal desa, kecamatan, kabupaten, propinsi dan nasional.

Akan halnya yang terjadi di Sampang Madura, konflik antara pengikut Sunni dan Syiah dianggap sebagai konflik keluarga yang terjadi di antara anak-anak dari KH Makmun yang dianggap sebagai ustadz pertama yang mengenalkan ajaran agama Islam Syiah kepada masyarakat di sekitarnya. Konflik di antara anak-anak KH Makmun sendiri yang kemudian meluaskan konflik Sunni-Syiah di Indonesia

Dari konflik yang awalnya dianggap perseteruan dalam keluarga KH Makmun, melebar menjadi konflik antar tetangga. Meluasnya konflik antar tetangga ini juga dikarenakan ulah atau perbuatan yang dilakukan oleh keluarga KH Makmun sendiri. Adu mulut yang dilakukan oleh keluarga $\mathrm{KH}$ Makmun dengan warga Sunni yang mencoba menghadang rombongan yang akan mengantar anakanak mereka kembali ke pondok pesantren di Bangil Pasuruan dan Pekalongan itulah yang menjadi pemicu juga bagi berkembangnya konflik antara warga Sunni dan Syiah yang ada di desa Karang Gayam kala itu. Adu mulut terjadi, karena warga Syiah merasa tidak melakukan kesalahan mengapa harus dihadang tidak boleh keluar dari desanya sendiri. Menurut salah seorang ulama MUI Sampang, penghadangan yang dilakukan oleh warga Sunni di desa tersebut adalah upaya untuk mencegah penyebaran Syiah yang lebih massive lagi. Dengan memulangkan kembali anak-anak mereka ke Ponpes Syiah, dikhawatirkan nantinya, mereka akan menjadi pengikut-pengikut Syiah seperti Tajul yang membahayakan di desanya. Kekhawatiran warga Sunni akan meluasnya pengaruh Syiah di desa tersebut membuat mereka mereka melakukan aksi pencegahan ini.

Dari konflik keluarga, merambatlah menjadi konflik komunal, antara warga Sunni melawan warga Syiah setelah matinya salah satu warga Syiah tersebut. Kemarahan warga Sunni tak terbendung lagi, hingga mereka membakar rumah, terutama rumah Tajul Muluk, rumah ustadz Iklil dan rumah Hani adik perempuan keduanya yang juga beraliran Syiah. Melebarnya konflik antar pribadi dalam keluarga, menjadi konflik komunal yang melibatkan jumlah orang dan korban yang bukan menjadi anggota keluarga, merambah pada perselisihan paham antar keduanya.

Saat setelah konflik (paska konflik) tahun 2012, warga pengikut Syiah di Sampang menjadi warga minoritas dengan diskriminasi hak-hak mereka sebagai warga negara. Misalnya, keluarga-keluarga Syiah yang melahirkan tidak bisa mengurus akte kelahiran. Begitu juga yang sudah menginjak usia 17 tahun tidak bisa memperoleh KTP. Bahkan kehidupan mereka menjadi semakin terpuruk. Anak-anak mereka juga dilarang untuk sekolah. Akhirnya, di antara warga Syiah sendiri saling urunan mengumpulkan uang untuk biaya pendidikan anak-anak warga Syiah lainnya. Mereka patungan agar anak-anak mereka bisa bersekolah dan memperoleh hak pendidikan.

Perselisihan antara kaum Sunni dan Syiah. Cerita yang beredar mengarah pada soal rejeki dan kekayaan. Menurut beberapa narasumber yang diwawancarai, kemarahan warga juga dipicu oleh adanya syak-wasangka bahwa warga Syiah di desa Karang Gayam dan Bluuran didanai oleh orangorang di luar daerah Madura. Misalnya, anak-anak mereka bisa sekolah ke Ponpes-Ponpes di luar Madura pasti karena dibayari oleh pihak lain. Hal ini karena kepercayaan orang Madura, hanya anak kyai atau orang kaya yang bisa menyekolahkan anaknya ke pondok pesantren di luar Madura karena biaya yang mahal. Menurut mereka, anak-anak Syiah sekolah di Ponpes Bangil dan Pekalongan tanpa mengeluarkan biaya sepeser pun dengan diberi biaya sekolah atau diberi beasiswa. Selain itu, kehidupan warga Syiah juga bergelimang barang mewah, gelang dan kalung emas, padahal mereka 
orang miskin yang tinggal di desa terpencil. Warga Sunni mencurigai ada pemberiaan aliran dana dari luar desa. Mereka menuduhkan dana diperoleh dari IJABI di Jakarta sebagai induk pengikut Syiah, bahkan juga didanai oleh instansi luar negeri, seperti Iran.

Keterlibatan dunia internasional seperti Iran dan Arab Saudi memang banyak dilansir beberapa pihak. Indikasi ini juga diperoleh karena hubungan dan masa lalu yang dilakukan oleh KH Makmun dan Tajul Muluk sendiri tidak terlepas dari jaringan mereka dengan "teman-teman" mereka di Timur Tengah setelah mereka pulang menempuh ilmu di sana. Hubungan yang kemudian difasilitasi oleh organisasi-organisasi Syiah di Indonesia, selain menguatkan prasangka bahwa keterlibatan pihak asing dalam konflik Sunni-Syiah di Sampang ini dipertimbangkan secara signifikan. Selain itu, terdapat pula pengaruh global meluasnya perjuangan kelompok-kelompok Islam fundamentalis seperti kelompok Takfiri, dan yang saat ini sedang ramai dibicarakan yakni kelompok ISIS (gerakan Negara Islam Irak dan Syiria).

\section{Isu-isu keagamaan yang terlibat}

Bagi pengikut Syiah, Sayiddina Ali dan keluarganya (istri dan dua anaknya, Hasan dan Husain) adalah yang lebih dihormati. Pemahaman terhadap ajaran Syiah sendiri, bagi pemeluk di luar Syiah, terutama pengikut Sunni menginterpretasi Syiah secara berbeda. Bagi pengikut Sunni apa yang dilakukan oleh Syiah adalah aliran sesat. Itulah mengapa orang Syiah dicap kafir oleh pengikut Sunni karena dianggap tidak mempercayai sahabat Nabi Muhammad yang empat orang tersebut. Persepsi yang kurang begitu dipahami akibat tidak memperlajari langsung ajaran Syiah, ditambah dengan rumor-rumor dan "katanya" membuat ulama Sunni di Sampang dan warga Sunni di Sampang semakin terbawa arus yang mengerucut pada pemutarbalikkan fakta yang ada. Kondisi yang pada akhirnya menyebabkan konflik berdarah yang berkepanjangan ketika kedua pihak yang berkonflik saling merasa benar dan tidak mau disamakan.

Konflik Sunni-Syiah di Sampang yang berkembang isunya juga menyatakan bahwa karena dakwah yang dilakukan oleh Tajul Muluk secara terbuka dengan menjelek-jelekkan sahabat Nabi melalui pengeras suara dari masjidnya. Hal ini menimbulkan warga Sunni merasa gerah. Sehingga mereka merasa dihina oleh Tajul. Tahun 2011 ketika Tajul dipenjara, tuduhannya adalah menghina agama. Roisul pun membuat pernyataan yang sama bahwa dakwah yang dilakukan Tajul dilakukan dengan terang-terang dan mengolok-olok orang Sunni. Ketika peneliti, mengonfirmasi hal ini kepada warga pengungsi Syiah, mereka menolak tuduhan itu. Menurut warga Syiah, ustadz Tajul tidak pernah melakukan itu. Itu hanya fitnah yang dilakukan oleh kelompok Roisul dan orang-orang yang tidak suka dengan mereka. Namun, keyakinan Syiah yang dianggap benar oleh kelompok Tajul dan pengikutnya dianggap bukan sebagai agama, atau Syiah yang sebenarnya oleh para ulama Sunni yang ada di Sampang. Seperti pernyataan berikut:

Syiah kan banyak sekte-sekte, kalau yang lain itu...yang ini Itsna Asyari yang Imam 12. Kalau sekte yang lain hanya mengidolakan Ali. Jadi yang berat ini yang imamah antara lain menganggap bahwa Imam yang dua belas itu Maksum, terpelihara dari dosa, derajatnya sama dengan nabi. Kemudian mengkafirkan sahabat yang tiga (Abu Bakar, Umar, dan Utsman). Kemudian menganggap istri-istri nabi itu pelacur kecuali Khadijah (KH. Sjuaib, MUI ampang).

Begitulah pandangan ulama tentang apa yang dilekatkan degan Syiah. Mereka beranggapan bahwa kelompok ini menjelek-jelekan Sunni dengan tidak mengakui sahabat nabi 3 lainnya, dan hanya mengakui Sayidina Ali. Meng-counter tuduhan ini, Ustadz Iklil menyatakan bahwa perbedaan Sunnah dan Syiah adalah pada keyakinan mereka: "Sunna percaya pada sahabat Nabi. Syiah percaya pada keluarga Nabi. Itu saja..semuanya sama, syahadatnya sama, solatnya sama, Al-Qur'annya sama."

Hal yang berbeda juga masalah Imam Mahdi. Pengikut Syiah percaya bahwa Imam Mahdi masih keturunan Nabi Muhammad yang akan datang bersama dengan Nabi Isa untuk menjaga kedamaian sebelum kiamat. Sementara itu, pengikut Sunni tidak percaya pada Imam Mahdi yang dipercaya Syiah. 
Menurut Sidel (2008), dalam banyak kasus kontestasi yang terjadi dalam konflik di Indonesia paska Orde Baru, dikonstruksi dalam kerangka batasan yang menandai identitas-identitas kolektif, dalam hal komunitas, klan, etnisitas, atau juga kepercayaan agama, di mana kelanggengan identitas sebenarnya sudah tidak ada lagi. Seperti yang diketahui bersama, kepercayaan agama di Indonesia dianggap sebagai penandaan identitas publik yang ditekankan oleh Orde Baru sebagai determinan kunci masuk kepada kelas politik (Sidel 2008: 31). Menarik apa yang disampaikan oleh Sidel, bahwa dalam konteks konflik horisontal dan vertikal, persoalan identitas agama menjadi faktor penentu. Dalam kasus Sunni-Syiah ini, ulama Sunni merasa benar dengan apa yang dikerjakannya selama ini sebagai Islam "yang benar." Mereka yang mengerjakan tidak sama dengan yang dikerjakan oleh kelompoknya dan keyakinannya dianggap "lawan" atau "menyimpang." Walaupun mereka tidak melihat secara langsung apa yang dilakukan. Identitas agama menjadi penting, untuk meletakkan posisi keelitan di tengah masyarakat yang miskin dan tidak tahu banyak tentang ilmu agama. Sehingga identitas keagamaan menjadi penting untuk merebut kontestasi legitimasi posisi elit di tengah masyarakatnya untuk menyebarkan pengaruh dan mempertahankan pengaruhnya.

\section{Dampak terhadap komunikasi antar-budaya}

Konflik Sunni-Syiah yang terjadi di Sampang pada tahun 2012 lalu tidak saja berdampak secara fisik dan psikologis kepada warga Syiah yang menjadi sasaran objek penyerangan massa yang anarkis. Namun konflik ini juga berdampak pada penyebaran atau perluasan diskusi publik nasional tentang Sunni dan Syiah yang dianggap berseberangan secara aqidah. Berbagai dampak yang terjadi akibat konflik ini tidak hanya kehilangan rumah dan kepemilikan, melainkan juga kehilangan identitas dan hak-hak kewarganegaraan dalam memeluk agama dan menjalankan ibadah mereka di masyarakat.

Rumah-rumah warga yang sudah terbakar habis di desanya membuat warga Syiah menjadi pengungsi yang harus berpindah dari awalnya di tempatkan di salah satu bangunan Sekolah Dasar di Kecamatan Omben, lalu direlokasi di GOR Sampang selama satu tahun, dan akhirnya ditempatkan di Rusun Puspa Agro sudah dua tahun tanpa kepastian pemulangan mereka baik oleh Pemerintah Daerah Jawa Timur, maupun pemerintah pusat Republik Indonesia. Kehidupan di Rusun yang hanya diisi dengan tempat tidur tanpa dipan, dan juga ruang tamu tanpa tempat duduk/kursi, warga pengungsi Syiah hidup dengan kondisi seadanya yang hanya menerima dana santunan dari pemerintah sebesar Rp. 750,000 per bulan harus menerima nasib yang sulit.

Untuk mengatasi kondisi kesulitan hidup, kaum perempuan pengungsi Syiah mencari pekerjaan yang bisa menghasilkan uang. Mereka awalnya menjadi pembersih ikan di pasar Agro Puspa yang berjarak 100 meter dari rusun mereka. Namun, pekerjaan ini kemudian hilang, karena berkurangnya pedagang ikan yang berjualan di pasar tersebut. Pada awal tahun 2014, ada pedagang kelapa yang menawarkan kepada para pengungsi perempuan untuk mengupas kelapa, dengan gaji antara Rp. 500,000-750,000 tergantung dari jumlah kilogram kelapa yang dikupas. Perempuan warga Syiah ini harus bekerja keras untuk mendapatkan tambahan uang tidak hanya tuntuk makan sehari-hari, tetapi juga untuk biaya kesehatan dan pendidikan sekolah anaknya yang tidak ditanggung pemerintah.

Warga Syiah menuntut ganti rugi kepada pemerintah atas hilangnya ladang-ladang, sawah-sawah, dan pemukiman mereka. Sebelum dipindah ke Rusun Jemundo, warga Syiah di Karang Gayam dan Bluuran mempunyai ladang yang ditanami tanaman produktif termasuk tembakau. Ketika terjadi konflik, tembakau yang waktunya panen harus dirusak dan dibakar. Mereka juga bercocok tanam seperti cabai, dan beberapa sayuran yang juga dirusak. Kehilangan sumber mata pencaharian akibat serangan itu menyedihkan sekaligus mengecewakan warga Syiah. Namun mereka mengaku sabar dengan musibah ini. Keyakinan agama mereka tidak tergantikan dengan kehilangan harta benda mereka. Masa depan bahkan tidak lagi terpikirkan. Keinginan pulang selalu ada, namun, tidak mungkin dilakukan. Warga Sunni tetap terprovokasi untuk menolak kehadiran Syiah di desanya. Walaupun beberapa warga Sunni yang ditemui di kedua desa tersebut, sebenarnya tidak mempermasalahkan kembalinya warga Syiah, karena mereka juga kasihan melihat saudaranya sendiri seperti itu. Apalagi masih banyak keluarga warga Syiah (yang tetap memeluk Sunni) yang tinggal di desa tersebut. 
Ustadz Iklil bahkan menuturkan bahwa hak-hak mereka sebagai minoritas bahkan semakin hilang setelah mereka diusir keluar dari Sampang. Seperti misalnya, tidak mempunyai akte kelahiran, KTP, dan pendidikan gratis yang disediakan. Kecuali jika mereka bertobat dan kembali menjadi Sunni. Negara sendiri membiarkan pengungsi Syiah dengan ketidakjelasan. Meskipun di media massa dikatakan pemerintah akan mengembalikan pengungsi namun semuanya tidak pernah terwujud. Menurut pengakuan Ustadz Iklil yang beberapa kali dengan perwakilan Syiah menemui Menteri Agama (Surya Dharma Ali) mengatakan selalu menemui jalan buntu. Menteri Agama selalu kembali memprovokasi untuk kembali memeluk Sunni agar bisa kembali ke Sampang. Selama warga Syiah tidak bersedia tobat dan memeluk Sunni, maka warga Syiah tidak akan pernah kembali. Namun, menurut istri Ustadz Tajul, untuk urusan politik pemilu, warga Syiah diminta untuk memilih. Ini yang tidak adil. Hak mereka sebagai warga Negara tidak diberikan, kecuali mobilisasi untuk pemilu RI yang dilakukan tahun 2012 bagi kemenangan wakil-wakil rakyat yang tidak pernah peduli dan memperhatikan warga Syiah.

Persebaran konflik Sunni versus Syiah yang terjadi di desa Karang Gayam dan Bluuran, akhirnya menjadi isu nasional. Konflik Sunni dan Syiah berkembang tidak hanya di Sampang, namun juga memicu terjadinya aksi kekerasan yang dilakukan oleh kelompok-kelompok Sunni garis keras di Indonesia seperti penyerangan di ponpes YAPI Bangil tahun 2013 dan juga penyerangan ponpes di Jember tahun 2014. Tidak hanya itu dampak dari konflik yang terjadi di Sampang tahun 2012, membawa perkembangan yang lebih tinggi lagi ketika para penyerangan-penyerangan dan aksi-aksi melawan keberadaan Syiah dilakukan oleh ulama-ulama MUI dan ulama-ulama Sunni garis keras di Bandung, Jawa Barat.

MUI Sampang menganggap Syiah aliran sesat. Begitu MUI pusat. Hingga MUI mengeluarkan buku Syiah sebagai aliran sesat. Sementara, sekelompok ulama Sunni di Bandung, mendeklarasikan kelompok anti Syiah untuk menentang keberadaan Syiah di Jawa Barat. Dampak dari konflik SunniSyiah ini juga adalah pelarangan warga Syiah mengikuti kegiatan ibadah dan melakukan kegiatan ibadah dan perayaan hari Asyura dan Idul Qodir di ranah publik. Hak-hak sebagai warga Negara untuk menjalankan agama dan ibadahnya tidak lagi mampu dilindungi oleh pemerintah. Meskipun hal ini melanggar UUD 1945 yang menjamin kemerdekaan menjalankan ibadah masing-masing. Syiah lalu dianggap sebagai "aliran sesat", "kafir", dan "komunis baru" di tengah masyarakat.

\section{Peran kyai sebagai tokoh agama, aparat desa, tokoh masyarakat, warga dan LSM lokal dalam penyelesaian konflik}

Kejadian di Sampang Madura membuat berbagai pihak masuk untuk ikut menyelesaikan pertikaian dua kubu yang berkonflik. Tidak hanya aparat Brimob, Polresta, dan juga pemerintah daerah, propinsi, dan pusat yang terlibat. Namun juga, lembaga-lembaga LSM pendamping yang melakukan advokasi bagi warga Syiah juga turut terlibat. Bahkan forum ulama (kyai), pengurus PCNU Sampang, MUI Sampang, dan juga lembaga keagaamaan Islam yang ada di Sampang dilibatkan untuk membahas konflik ini.

Menurut pengurus cabang NU Sampang, sebenarnya ulama Sampang bersama unsur keamanan telah melakukan pertemuan dengan wakil-wakil dari warga Sunni dan Syiah yang berseteru. Namun, forum ini tidak menghasilkan titik temu atau jalan damai, malah memperkeruh keadaan. Hal ini karena hasilnya, ulama dan Bupati Sampang serta MUI Sampang meminta warga Syiah untuk tobat dan kembali memeluk Sunni baru mereka boleh kembali ke daerahnya. Hal yang ditolak mentah-mentah oleh warga Syiah.

Salah seorang ulama menuturkan bahwa, kyai Sunni di Sampang sebenarnya telah terlibat dalam upaya mencari jalan damai. Tetapi warga Syiah yang tidak bersedia. Demikian versi yang disampaikan oleh salah satu ulama Sampang. Forum pertemuan yang dilakukan oleh ulama Sampang dan aparat keamanan di Sampang tidak memberikan hasil yang positif bagi konflik Sunni-Syiah ini. Menurut pengakuan warga Syiah, memang pernah ada upaya rekonsiliasi yang dilakukan pada tahun 2013. Ketika perwakilan warga Sunni Sampang mendatangi warga Syiah di tempat pengungsi untuk 
bersama-sama menandatangani kesepakatan damai dan rujuk antar warga yang bersetru. Namun, menurut penuturan warga Syiah pertemuan dan perjanjian itu hanya isapan jempol saja. Kelihatannya di media massa mereka telah rujuk. Kenyataannya warga Sunni, yang dipengaruhi elit ulama di sana, tidak menjalankan perjanjian yang ditanda tangani bersama.

\section{Simpulan}

Konflik yang terjadi atau muncul sekitar tahun 2006, terus bergulir hingga tahun 2012, puncaknya adalah pembakaran rumah pemimpin ajaran Syiah. Perbedaan meyakini apa yang mereka dapatkan dari teman, dari lembaga pendidikan pondok pesantren, dan dari kitab-kitab yang mereka baca, menjadi pemicu konflik. Terlebih, ketika fitnah dan omongan dari mulut ke mulut seperti "katanya" tanpa menyaksikan langsung apa yang dikerjakan oleh pengikut Syiah, warga pengikut Sunni mudah sekali terpancing untuk menyatakan pengikut Syiah sebagai penganut aliran sesat, kafir, dan menistakan agama. Selain itu, faktor kemiskinan dan pendidikan yang rendah, serta kefanatikan masyarakat terhadap pemimpin sekaligus guru agama mereka, membuat masyarakat tidak pernah berpikir panjang untuk mengikuti pengaruh dan dakwah yang diajarkan dalam pengajian-pengajian mereka. Bahkan, banyak kemudian keluarga-keluarga yang mengirim anaknya ke pesantren-pesantren kecil lokal untuk belajar agama kepada ulama yang mereka anggap "benar" mengajarkan tentang Islam.

Konflik Sunni-Syiah di Sampang, memberikan banyak cerita dan persoalan yang krusial untuk ditangani oleh berbagai pihak di daerah, provinsi, maupun ditingkat republik. Dari hasil penelitian yang dilakukan, bisa disimpulkan beberapa hal berikut: Pertama, konflik dipicu oleh cara-cara dakwah yang dilakukan oleh pemimpin (clerics) Syiah terhadap warga di sekitarnya. Kedua, konflik juga dipicu oleh kurang pahamnya masyarakat setempat terhadap ajaran agama Islam yang mereka anut dan yakini. Kemiskinan dan rendahnya tingkat pendidikan membuat warga begitu saja menerima dengan mudah ajaran orang yang dianggap tinggi ilmunya seperti ustadz ataupun kyai setempat. Ditambah dengan kefanatikan mereka terhadap kyai atau ustadz, maka apa yang disampaikan itulah yang dianggap benar dan harus dipertahankan hingga tetes darah terakhir. Ketiga, konflik keluarga para elit Syiah di desa Karang Gayam dan desa Bluuran menjadi konflik publik yang melibatkan urusan pribadi ke ranah publik dengan kedua belah pihak saling menjelek-jelekkan satu sama lain, saling memfitnah, dan tidak bisa lagi duduk bersama berdialog tentang keyakinan dan kitab yang mereka miliki, seolah toleransi beragama tidak ada lagi dalam kehidupan mereka. Meskipun keinginan warga Syiah agar warga Sunni bisa menerima perbedaan tidak digubris oleh warga, terutama ulama Sunni, selama warga Syiah tidak menyatakan tobat dan kembali memeluk Sunni. Keempat, ada motivasi politik yang dimiliki oleh pihak yang berseteru yakni antara ustadz Tajul Muluk, dan Roisul Hukama. Kondisi ini diperparah dengan masuknya otoritas Sampang, yakni mantan Bupati Nur Tjahya yang memperkeruh hubungan Sunni-Syiah. Kelima, motivasi ekonomi yang muncul karena persaingan di antara para "elit kyai dan ustadz lokal" di Kecamatan Omben dan Karang Penang serta daerah sekitar di Sampang.

Keterlibatan kyai dan ustadz lokal di Sampang menjadi krusial dalam konflik ini. Para ulama ada yang menjadi inisiator perdamaian. Namun, sebagian besar menolak berdamai selama warga Syiah tetap memeluk Syiah. MUI Sampang bahkan menganggap Syiah aliran sesat yang harus diusir dari Sampang. Alhasil, warga Sunni tertentu bahkan memperlakukan warga Syiah sebagai orang najis yang harus dijauhi. Pemerintah daerah Sampang yang harusnya bisa memfasilitasi konflik ini, menjadi bagian dari ulama Sampang yang menolak kembali pemulangan warga Syiah sebelum mereka bertobat. Senada dengan Pemda Sampang, Pemprov Jawa Timur dan juga pemerintah pusat, dalam hal ini Kemenag, mempunyai sikap yang sama. Tidak ada lagi harapan warga Syiah untuk kembali pulang dan memiliki kebun, ladang dan rumah yang mereka miliki.

Pada akhirnya upaya untuk melakukan rekonsiliasi harus dilakukan sendiri melalui warga masyarakat. Oleh karena itu penelitian ini, merekomendasikan dibentuknya forum-forum Komunikasi dan dialog antar pemeluk Sunni dan Syiah yang dilakukan atas inisiatif masyarakat setempat, terutama kaum perempuan yang mampu dijadikan wilayah untuk masuk dalam proses rekonsiliasi ini. Perempuan 
mempunyai kekuatan dan dinamika yang memungkinkan untuk masuk dalam upaya-upaya perbaikan hubungan pada kelompok-kelompok yang berseteru. Selain itu, peran ulama yang lebih netral diperlukan juga sebagai pihak-pihak yang menginisiasi rekonsiliasi ini. Oleh karena itu pentingnya mencari dan mengumpulkan ulama-ulama netral untuk membantu proses perdamaian di Sampang. Inilah yang akan dilakukan dalam penelitian tahap selanjutnya.

\section{Daftar Pustaka}

Colombijn F \& Thomaslindblad J (2002) Roots of Violence in Indonesia. Leiden: KITLV.

Sidel JT (2008) The Manifold Meanings of Displacement: Explaining inter-religius violence 19992001. Dalam: Hedman LE (ed). Conflict, Violence, and Displacement in Indonesia: Cornell Southeast Asia Program, Cornell University.

Varshne A, Panggabean R, dan Tadjoeddin MZ (2004) Patterns of Collective Violence in Indonesia (1990-2003), Jakarta: UNSFIR.

Yayasan Wakaf Paramadina (YWP) (2009) Laporan Tahunan Konflik Antar Agama dan Etnik di Indonesia tahun 2009. Magister Perdamaian dan Resolusi Konflik, Universitas Gadjah Mada (MPRK-UGM) dan The Asia Foundation (TAF), Yogyakarta: MPRK-UGM. 